NBER WORKING PAPER SERIES

\title{
THE EFFECT OF DEMOGRAPHIC FACTORS \\ ON AGE-EARNINGS PROFILES
}

Richard B. Freeman

Working Paper No. 316

NATIONAL BUREAU OF ECONOMIC RESEARCH 1050 Massachusetts Avenue

Cambridge MA 02138

February 1979

I have benefitted from the comments of Richard Layard and the referees. The research reported here was supported by U.S. Department of Labor Grant 21-25-78-19 and is part of the NBER's research program in labor economics. Any opinions expressed are those of the author and not those of the National Bureau of Economic Research. 
The Effect of Demographic Factors on Age-Earnings Profiles

\section{ABSTRACT}

This paper examines the effect of the increased number of young persons on the job market on their earnings relative to the earnings of older workers. The principal finding is that the age-earnings profile of male workers appears to be significantly influenced by the age composition of the work force. When the number of young workers increased sharply in the 1970s, the profile "twisted" against them, apparently because younger and older male workers are imperfect substitutes in production. The effect of changes in the relative numbers of workers of different ages on age-earnings profiles is especially marked among college graduates. By contrast, the age-earnings profile of female workers, which tends to be quite flat, appears to be little influenced by the age composition of the female work force, possibly because the intermittent work experience of women makes younger women and older women closer substitutes in production.

Whether the sizeable decline in the earnings of the large cohort of young workers entering the market in the 1970 s relative to the earnings of older cohorts will persist, creating a lifetime "size of cohort" earnings effect, or whether the new entrants of the 1970s will significantly catch up in earnings in future years remains to be seen. The dependence of the ageearnings profile on demographically-induced movements along a relative demand schedule suggests that standard human capital models of the profile, which posit that earnings rise with age or experience solely as a result of individual investment behavior are incomplete.

Richard B. Freeman

National Bureau of Economic Research 1050 Massachusetts Avenue Cambridge, MA 02138 (617) $868-3915$ 
The age distribution of the labor force varies greatly over time in response to longterm demographic changes. Historically high birth rates produce a relatively large number of younger labor force participants and an age distribution skewed toward younger ages while historically low birth rates have the opposite impact. ${ }^{1}$ Because of the "baby boom" that followed World War II and peaked in 1955-60 (U.S. Bureau of the Census, 1977, p. 56), there was an especially significant change in the age structure of the U.S. work force in the late 1960s and early 1970s, when the number of young persons increased extremely rapidly. From 1966 to 1976 the number of labor force participants aged 20-24 grew from 9.7 million to 16.7 million while the number aged $25-34$ grew from 16.9 million to 23.0 million. The ratio of participants less than 35 years of age to participants 35 and over jumped from .46 to $.67 .^{2}$

What are the consequences for the wage structure of such sizeable changes in the age composition of the labor force? Does an increase in the relative number of young workers alter their wages relative to the wages of older workers? To what extent do cross-sectional age-earnings profiles respond to exogenous demographic shifts? What are the possible implications of the experience of the late 1960s and 1970s for the decade of the 1980s, when the number of young workers is expected to decline?

The answers to these questions depend on the degree of flexibility of relative wages by age or, in the context of standard labor demand analysis, on elasticities of complementarity (Hicks, Sato and Koizuma) which link changes in factor prices to changes in the supply of inputs. If the relevant elasticities are large, changes in the age composition of the labor force can substantially alter age-earnings profiles whereas 
if the elasticities are small, profiles will be relatively independent of the number of workers in different age groups.

This paper studies the effect of changes in the age structure of the work force on age-earnings profiles in the U.S. and provides estimates of the relevant elasticities of complementarity for young and older workers. It focuses in particular on developments in the late 1960 s and in the 1970 s, when the relative number of young workers increased sufficiently rapidly as to: provide a strong "test" of the potential dependence of the profile on exogenous shifts in the age structure of the labor supply. Section one documents the magnitude of the change in the age structure of the work force which constitutes the "experimental" variation under study. Section two presents evidence from the Current Population Surveys of the U.S. Bureau of the Census that the age-earnings profile of male workers changed in the period, with the ratio of the earnings of older men to the earnings of younger men rising sharply. Section three develops the relevant labor demand and production function models needed to analyze the link between changes in the age structure of the work force and changes in age-earnings profiles. Section four estimates the extent to which shifts in ageearnings profiles can be attributed to demographically induced movements along labor demand schedules whose magnitude is reflected in the relevant elasticities of eomplementarity.

The principal finding is that the age-earnings profile of male workers, which has traditionally been viewed as a stable economic relation determined by human capital investment decisions, appears to be significantly influenced by the age composition of the work force. Apparently because younger and older male workers are imperfect substitutes in production, changes in the number of young male workers relative to older male workers substantially influences the ratio of the earnings of younger men to the earnings of older nen. 
The effect of changes in the relative numbers of workers of different ages on age-earnings profiles is especially marked among college graduates. By contrast, the age-earnings profile of female workers, which tends to be quite flat, appears to be little influenced by the age composition of the female work force, possibly because the intermittent work experience of women makes younger women and older women closer substitutes in production. Whether the sizeable decline in the earnings of the large cohort of young workers entering the market in the 1970s relative to the earnings of older cohorts will persist, creating a lifetime "size of cohort" earnings effect or whether the new entrants of the 1970 s will significantly catch up in earnings in future years remains to be seen.

The dependence of the age-earnings profile on demographically-induced movements along a relative demand schedule suggests that standard human capital models of the profile, which posit that earnings rise with age or experience solely as a result of individual investment behavior are incomplete. If, as found in this study, elasticities of substitution or complementarity among age groups are not infinite, human capital cannot be treated as a homogeneous input with a single rental price, whose "units" of investment determine the age-earnings profiles. Differences in the activities of young and old workers and the underlying demand for those activities decisively influence the shape of the profile. To understand the relation between earnings and age, it is necessary to analyze the demand for workers by age and employer personnel policies as well as to analyze human capital investment decisions. 


\section{The Changing Age Structure of the Work Force}

The broad outlines of the remarkable change in the age structure of the work force of the United States under investigation is examined in Table 1, which records the absolute number of workers aged 20-24 and 25-34 and the number aged 20-24 and 25-34 relative to the number of workers aged 35 and over for the period 1966 to 1976. The table treats male and female workers and college graduates and high school graduates separately. These patterns of change stand out in the table: a remarkable increase in the number of young workers in total, the result of the "baby boom" that followed World WarII;an even greater percentage increase in the number of young college graduate workers, the result of the unprecedented proportion of young persons choosing to enroll in college in the 1960s; and an especially marked increase in the number of young female workers, the result of a sizeable jump in the labor participation rate of young women in the late 1960 s and 1970s.

Among male workers, the numbers aged 20-24 and 25-34 increased by over one-third from 1966 to 1976 while the number of college graduates aged 20-24 and aged 25-34 more than doubled. As a result of these changes, the ratio of all male workers $20-34$ to those 35 and over rose from .55 in 1966 to .78 in 1976 while the ratio of male college graduate workers 20-34 years of age to male college graduate workers 35 and over increased from .62 (1966) to 1.02 (1976). According to the figures in Panel B, the number of female workers aged 20-24 increased by $76 \%$ while the number aged 25-34 increased by $103 \%$. These gains outstripped the rate of increase of the older female work force by sufficient magnitudes to raise the ratio of $20-24$ to $35+$ year old female workers by $53 \%$ and the ratio of 25-34 to $35+$ year old female workers by $76 \%$. Among college graduate workers, the number of young 
women aged 20-24 more than doubled while the number aged 25-34 more than tripled. While less dramatic, the number of young female high school graduate workers also increased, particularly in the 25-34 bracket.

Data on the number of new high school and college graduates and on the number of new graduates entering the labor market tell a similar story about the influx of young persons into the work force, though the timing of changes necessarily differs from that in Table 1 . Between 1960 and 1970 the number of new high school graduates per thousand persons in the civilian labur force rose from 26.8 to $35.0 .^{3}$ From 1960 to 1972 the number of high school graduates and dropouts entering the job market grew from 13.2 per thousand members of the civilian labor force to 17.1 per thousand members of the civilian labor force. ${ }^{4}$ For college graduates the picture is more complex, as the tendency to enroll for graduate studies in the 1960s delayed the labor market entrance of the large classes of the sixties until the following decade. From the late 1960s to the mid 1970s, however, the ratio of new bachelor's graduates on the market to the civilian labor force increased sharply. 5

Because data on graduates refer to flows rather than stocks of persons in a wide age grouping, they reveal further the beginning of the decline in the number of young workers which will mark the 1980s. From 1972 to 1977 the persons graduating from high school grew by a bare 4\% (U.S. Bureau of the Census, p. 153). From 1974 to 1976 , the number of persons graduating from college fell by $3.0 \%$ (op. cit., p. 153). The beginning of the demographic change from the large cohorts of young persons of the late 1960 s and 1970 s to the smaller cohorts of young persons of the 1980s can be seen in these figures. 


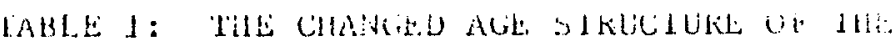

WORK FORCE, BY SEX AND EDUCATION

Work Force, by Age

Numbers Relative to

(in thousands) Workers 35+

$\underline{20-24} \quad 25-34 \quad 20-24 \quad 25-34$
College Graduate Work Foree, By Age Hgh School Graduate Work Force, by Age Numbers Relative to

(in.thousands) College Workers

20-24 $25-34 \quad \underline{20-24} \quad \underline{25-34}$

\section{Numbers Relative to}

(in thousands)

$\underline{20-24} \quad \underline{25-34} \quad \underline{20-24} \quad \underline{25-34}$

A. Male Workers

$\begin{array}{lcccccccccccc}1966 & 6,139 & 10,761 & .201 & .352 & 280 & 1,067 & .129 & .490 & 2,057 & 3,929 & .249 & .475 \\ 1968 & 6,788 & 11,376 & .221 & .371 & 290 & 1,137 & .131 & .514 & 2,066 & 4,220 & .232 & .473 \\ 1970 & 7,378 & 11,974 & .241 & .391 & 376 & 1,200 & .161 & .514 & 2,324 & 4,529 & .248 & .483 \\ 1972 & 7,795 & 12,806 & .257 & .423 & 567 & 1,393 & .232 & .569 & 2,772 & 4,792 & .288 & .497 \\ 1974 & 8,105 & 13,993 & .270 & .465 & 583 & 1,725 & .222 & .655 & 3,011 & 5,110 & .289 & .507 \\ 1976 & 8,421 & 14,990 & .282 & .502 & .686 & 2,203 & .242 & .779 & .3,334 & 6,309 & .330 & .525 \\ \% \text { change } & 37.2 & 39.3 & 40.2 & 42.6 & 145.0 & 106.5 & 84.7 & 59.0 & 62.1 & 60.5 & 42.2 & 11.0 \\ 1966-76 & & & & & & & & & & & & \end{array}$

R. IIMAIE WORKERS

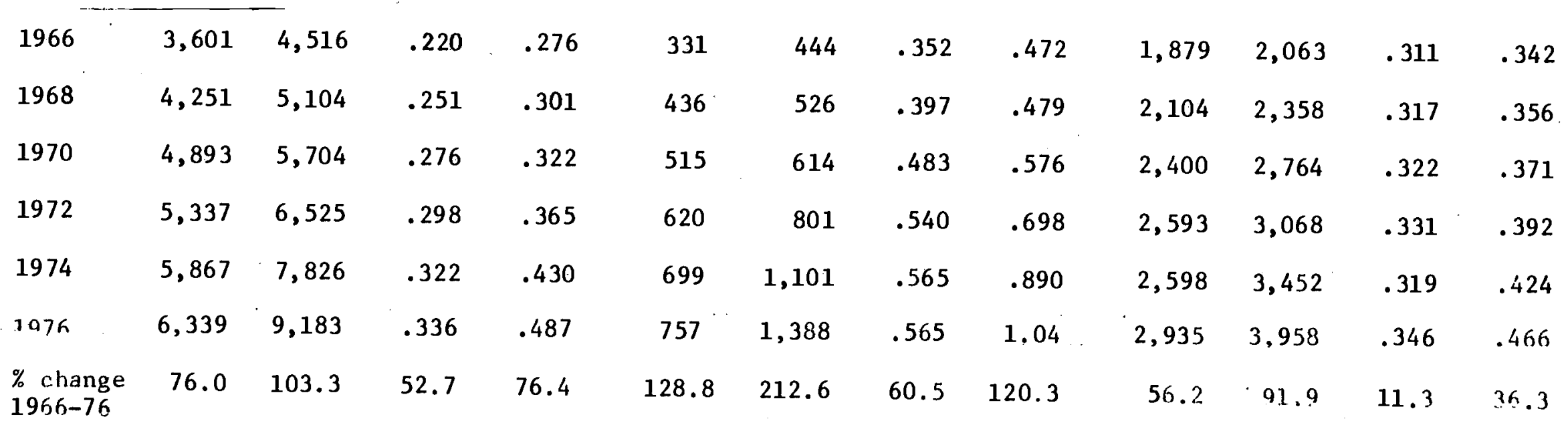

Work force data compiled from U.S. Department of Labor, Employment and Training Report of the President, transmitted to Congress 1977, Table A-2, p. 137.

Workers by education data compiled from I.S. Department of Labor, Bureau of Labor Statistics, "Fitucatfonal Attainment of Workers," Special Labor Force Reports, various editions. 
While not a "classical experiment" with all other factors held fixed, the sizeable increase in the number of young workers found in Table 1 and in the graduates data cited above and the concurrent change in the age composition of the work force constitutes the type of exogenous shift in the age composition of the work force that should provide a reasonably strong test of whether the age-earnings relation depends on factors beyond investments in training. Was the change in supply accompanied by changes in relative wages?

\section{Changes in the Relative Earnings of Yonng Workers}

Evidence on earnings by age from the Current Population Survey of the Bureau of the Census provides an answer to this question. The CPS data show that for male workers, who traditionally have had steep cross-sectional age-earnings profiles, the demographic changes of the late 1960s and of the 1970 s were accompanied by a substantial "twist" in the age-earnings profile against the young. By contrast, among female workers, who have traditionally had flat age-earnings profiles, the demographic changes do not appear to have altered the relative wages of the young. While other factors (to be explored in section IV) may have also been at work, the concatenation of increases in relative numbers and decreases in relative wages in the period is highly suggestive of movement along a negatively sloped demand curve, with a moderate elasticity of substitution between workers of different ages.

Table 2 summarizes the CPS evidence on age-earnings profiles in terms of the ratio of the income or earnings of 45-54 year old workers to the incomes or earnings of 20-24 or 25-34 year old workers, in toto 
and for high school graduates and college graduates taken separately. The figures in lines $1-8$ are taken from the U.S. Bureau of the Census' Current Population Reports, with the data for 1975 adjusted to take account of changes in the imputation procedure used by the Census. As discussed in Current Population Reports, Consumer Income Series P-60, No. 105, the Census made major changes in its method of computing estimates in 1975 when it introduced a new imputation procedure to estimate missing records. The new procedure tends to raise the average earnings of more educated and older workers relative to what would have resulted from the previous imputation procedure. For comparability over time, the 1975 data in the table are adjusted to a pre-1975 basis by multiplying the reported 1975 figures by the ratio of incomes in 1974 calculated from the old imputation procedure to incomes in 1974 calculated from the new procedure, using unpublished Census tabulations. 6

Lines 1-4 treat the mean incomes of all workers who report greater than zero values for the year. These incomes are likely to be sensitive to cyclical changes in unemployment rates. Lines 5-8 are based on the incomes of yearround full-time workers, which should be less sensitive to the cycle and which should offer a better measure of rates of pay than the incomes of all workers. For women, the sizeable number of part-time workers and significant non-wage incomes makes interpretation of the incomes for all workers complex, suggesting that attention be focused on year-round full-time employees. The final lines of the table record ratios of usual weekly earnings. These figures have the advantage of refering to labor market earnings rather than total incomes and of covering narrower age groups. They suffer from lack of information on years of schooling.

The figures for male workers in the table show a substantial change 
Table 2: Ratios of the Incomes or Earnings of Older to Younger Workers by Sex and Education, 1967-1977

Income measure and group

$\frac{\text { Males }}{1967-68^{\mathrm{a}} 1975^{\mathrm{b}} \quad: 977} \frac{\text { Females }}{1967-8^{\mathrm{a}} 1975^{\mathrm{b}} \quad 1977}$

Mean Incomes of All Workers

1) Ratio of the income of persons aged 45-54 to the income of persons aged 20-24

$\begin{array}{lllll}2.30 & 2.50 \quad- & 1.38 & 1.48\end{array}$

2) Ratio of the income of persons aged 45-54 to the income of persons aged 25-34

$\begin{array}{lllll}1.18 & 1.23 \quad-\infty & 1.16 & 1.05\end{array}$

3) Ratio of the income of persons aged 45-54 to the income of persons aged 25-34

$\begin{array}{lllll}1.21 & 1.30 \quad- & 1.24 & 1.13\end{array}$
High School graduates

4) Ratio of the income of persons aged 45-54 to the income of persons aged 25-34 1.43 1.62 $-\quad 1.35$

1.22 College graduates

Mean Incomes of Year-round and Full-time Workers

5) Ratio of the income of persons aged 45-54 to the income of persons aged 20-24

$\begin{array}{lllll}1.74 & 2.00 \quad-- & 1.21 & 1.35\end{array}$

6) Ratio of the income of persons aged 45-54 to the income of persons aged 25-34

$1.18 \quad 1.26 \quad-\quad 1.00 \quad 1.01$

7) Ratio of the income of persons aged 45-54 to the income of persons aged 25-34

$1.20 \quad 1.31 \quad-\quad 1.07 \quad 1.08$
High School graduates

8) Ratio of the income of persons aged 45-54 to the income of persons aged 25-34 College graduates

$\begin{array}{llll}1.38 & 1.63 \quad-- & 1.05 & 1.14\end{array}$

Mean Usual Weekly Earnings, Full-time White Workers

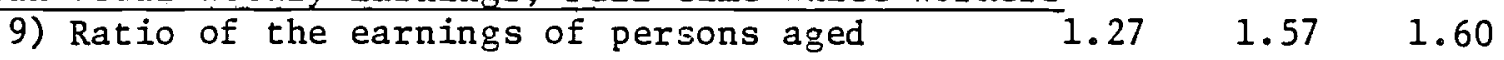
45-49 to the earnings of persons 20-24 Out of school workers

10) Ratio of the earnings of persons aged $\quad \begin{array}{llll}1.06 & 1.19 & 1.21\end{array}$ 45-49 to the earnings of persons $25-29$

Source: U.S. Bureau of the Census, Current Population Reports, Consumer Income Series P-60, No. 66, tables 39, 41; No. 101, tables 53, 59; No. 105, table 4/.

U.S. Department of Labor Bureau of Labor Statistics. Inpublished tabulations from May 1967, 1975 and 1977 Current Population Surveys.

$a_{1968}$ in lines $1-8 ; 1967$ in lines $9-10$

${ }^{b}$ Figures for 1975 in lines 1-8 based on unpublished Census data which gives incomes in 1974 and 1975 on a comparable basis. As disçussed in Series P-60, No. 105, the Census used a different imputation procedure for estimating incomes in 1975. The new procedure tends to bias upward the earnings of more educated and older workers. 
in age-earnings profiles, with the income or earnings of older men rising sharply relative to the income or earnings of younger men: For all men, the data in lines 1 and 2 show an increase of 20 points in the ratio of the incomes of 45-54 year olds to the income of 20-24 year olds and an increase of 5 points in the ratio of the incomes of 45-54 year olds relative to the income of 20-24 year olds. The comparable changes for year-round and ful1-time workers in lines 5 and 6 are 24 points and 8 points. With the best measures of rates of pay, median usual weekly earnings, there is a rise in the ratio of the earnings 'of $45-49$ year olds to the earnings of $20-24$ year olds not enrolled in school of 33 points from 1967 to 1977 and a rise in the ratio of the earnings of 45-49 year olds to the earnings of 25-29 year olds of 15 points.

The figures for college and high school graduates show further that the "twist" in male age-earnings profiles was most pronounced for college graduates. Between 1968 and 1975 the ratio of the incomes of 45-54 year old year-round and full-time male college graduates to the incomes of 25-34 year old yearround and full-time male college graduates rose by 25 percentage points or 18 percent while the comparable ratio for male high school graduates rose by 11 points or 9 percent. Similarly, for all male college graduates, the ratio of the incomes of 45-54 year olds to the incomes of 25-34 year olds rose by 19 percentage points while the ratio of the incomes of high school graduates $45-54$ years old to the income of high school graduates $25-34$ years old rose by just 9 percentage points.

The data for women tell a different story. The mean incomes for all workers show a rise in the income of women aged 45-54 relative to the income of women aged 20-24 but do not show a rise in the income of women aged 45-54 to the income of women aged 25-34 and depict a drop in the income of older high school or college graduate women relative to younger high school or college graduate women (1ines 3,4). On the other hand, the mean incomes for year-round and full-time workers show an increase in the ratio of the income 
of 45-54 year olds compared to the income of 20-24 year olds but not compared to the incomes of 20-24 year olds. The unclear pattern in the data may reflect the general flatness of the age-earnings profile for women, particularly for year-round and full-time workers. If the flat profiles result from high substitutability between workers of different ages in production, ${ }^{7}$ large changes in the age structure of the population would have little or no impact on the profiles.

Because age-earnings profiles differ markedly between men and women and appear to have changed only for men in the period covered, the remainder of this study will focus solely on male age-earnings relations. The flat and apparently stable profiles among women suggest very different economic processes at work, which merit separate detailed study beyond the scope of the current inquiry.

\section{Analysis of male earnings using CPS data tapes}

More precise estimates of the extent of change in the age-earnings profiles of male workers can be obtained by linear regression analysis of the effect of age on earnings using the CPS data on individuals that underlies the published aggregates. Regression analysis of the data for Individuals has several advantages over comparisons of published means: it permits investigation of labor market earnings (rather than of incomes, as given in Current Population Reports Series P-60); it permits calculation of weekly earnings (yearly earnings over weeks worked) as an indicator of rate of pay; it allows for greater disaggregation of workers by age and education; and it can be used more readily to make statistical tests of the significance of observed changes. 8

To estimate changes in age-earnings profiles among male workers in the period under study using CPS data on individuals, the following linear regression model was fit with the March 1969 and March 1978 tapes ${ }^{9}$ (which give incomes for the preceding year):

$$
\text { (1) } \quad \operatorname{lnw}_{i j}=a+\sum_{i j} b_{i j} E_{i} A_{j}+R_{i j}+\mu_{i j}
$$


Table 3: Regression Estimates and Standard Errors on the Difference Between the Log of Earnings of Men Aged 45-54 and of Younger Men, for College and High School Graduates, 1968 and 1977

\begin{tabular}{|c|c|c|c|c|c|c|c|c|}
\hline \multirow{2}{*}{$\begin{array}{l}\text { Education and } \\
\text { Age Group } \\
12 \text { years of } \\
\text { Schooling }\end{array}$} & \multicolumn{2}{|c|}{$\begin{array}{l}\text { Coefficient and Stan- } \\
\text { dard Errors for Earn- } \\
\text { ings of } 45-54 \text { Year olds } \\
\text { Relative to Other Group } \\
\text { Week1y Earnings } \\
1968 \quad 1977 \\
\end{array}$} & $\begin{array}{c}\text { Change in } \\
\text { Relative } \\
\text { Earnings }\end{array}$ & $\begin{array}{c}t \text {-Test of } \\
\text { Change }\end{array}$ & \multicolumn{2}{|c|}{$\begin{array}{l}\text { Coefficient and Stan- } \\
\text { dard Errors for Earn- } \\
\text { ings of } 45-54 \text { Year olds } \\
\text { Relative to Other Group } \\
\text { Yearly Earnings } \\
1968 \quad 1975\end{array}$} & $\begin{array}{r}\text { Change in } \\
\text { Relative } \\
\text { Earnings }\end{array}$ & $\begin{array}{l}t \text {-Test } \\
\text { Chang }\end{array}$ \\
\hline & & & & & & & & \\
\hline $18-24$ & $.60(.03)$ & $.78(.06)$ & .18 & 2.57 & $.95(.03)$ & $1.02(.08)$ & .17 & 1.89 \\
\hline $25-29$ & $.13(.03)$ & $.30(.06)$ & .17 & 2.43 & $.17(.03)$ & $.37(.08)$ & .20 & 2.22 \\
\hline $30-34$ & $.02(.03)$ & $.11(.06)$ & .09 & 1.29 & $.02(.03)$ & $.16(.08)$ & .14 & 1.56 \\
\hline $35-44$ & $-.03(.03)$ & $.07(.06)$ & .10 & 1.43 & $.03(.03)$ & $.08(.08)$ & .06 & 0.67 \\
\hline $45-54$ & .00 & .00 & - & -- & .00 & .00 & -- & -- \\
\hline $\begin{array}{l}16 \text { years of } \\
\text { Schooling }\end{array}$ & & & & & & & & \\
\hline $18-24$ & $.83(.05)$ & $1.03(.06)$ & .30 & 3.75 & $1.18(.06)$ & $1.48(.11)$ & .30 & 2.31 \\
\hline $25-29$ & $.28(.05)$ & $.58(.07)$ & .30 & 3.33 & $.37(.05)$ & $.70(.10)$ & .33 & 3.00 \\
\hline $30-34$ & $.10(.05)$ & $.40(.07)$ & .30 & 3.33 & $.10(.05)$ & $.47(.10)$ & .37 & 3.36 \\
\hline $35-44$ & $.01(.04)$ & $.18(.07)$ & .17 & 2.14 & $.02(.05)$ & $.21(.10)$ & .19 & 1.73 \\
\hline $45-54$ & .00 & .00 & -- & - & .00 & .00 & -- & -- \\
\hline $\begin{array}{l}\text { No. of } \\
\text { bservations }\end{array}$ & 30,231 & 29,842 & - & - & 20,231 & 29,842 & -- & -- \\
\hline $\mathrm{R}^{2}$ & .248 & .272 & -- & -- & .297 & .284 & - & -- \\
\hline
\end{tabular}

${ }^{a}$ The significance for the $t$ tests are: $5 \% 1$ eve1, $1.65 ; 1 \% 1$ evel, 2.33

Source: Obtained by regression of the log of earnings on dummy variable for race and education by age, as described in the text. The regressions included age-education dumny varlables for the following education groups: 0-8 years of education, 9-11 years of education, 13-15 years of elucation, 17 and 18+ years of educat 10 n and for 55-64 year olds in addition to the groups in the table. The March 1969 and March 1978 Current Population Survey Tapes were used In the analysiss. 
where $W_{i j}=$ weekly or annual earnings of workers in the ith education and jth age groups,

$E_{1}=$ dichotomous dumny variable that takes the value 1 for persons in the ith education group and the value 0 otherwise, with $i$ covering seven education groups: 0-8 years of schooling, 9-11 years, 12 years, 13-15 years, 16 years, 17 years, and more than 17 years.

$A_{j}=$ dichotomous dummy variable that takes the value 1 for persons in the $j$ th age groups and 0 otherwise, with $j$ covering six age groups, $18-24,25-29,30-34,35-44,45-54$, and 55-64.

$\mathbf{R}_{i j}=$ dummy variable which takes the value 1 for blacks $\mu_{i j}$ is assumed $N\left(0, \sigma^{2}\right)$.

The results of the calculations are summarized in Table 3 in terms of differences between the coefficients on the log earnings of workers aged 45 to 54 and the coefficients on the log earnings for workers in younger age brackets for persons with 12 years of schooling (e,g, hịg school graduates) and for persons with 16 years of schooling (e.g. college graduates), taken separately. Comparable estimates for other education groups are also available, but for simplicity are not given in the table. In the left side of the table the dependent variable is the log of weekly earnings, the best measure of rates of pay on the March CPS files. The right hand side of the table treats the log of annual earnings. The computations confirm the finding of a sizeable decline in the earnings of young workers relative to the earnings of older workers, particularly among the more educated. Among high school graduates, the log weekly earnings of 45-54 year olds is 18 log points higher relative to the log weekly earnings of 18-24 year olds in 1977 than in 1968; is .17 points higher relative to the log earnings of 25-29 year olds in 1977 than in 1968; is .09 points higher relative to the log earnings of 30-34 year olds in 1977 than in 1968; and is 10 points higher relative to the log earnings of 35-44 year olds in 1977 than in 1968. Among men with four years of college, the changes are greater, with increases of $30 \mathrm{log}$ points in the difference between the log earnings of 45-54 year olds and 
the $\log$ earnings of $18-24,25-29$, and $30-34$ year olds respectively from 1968 to 1977 . In other education groups, the results are comparable. While not all of the changes in the difference in log earnings are significant at the $5 \%$ level, those for the more educated group are highly significant.

The calculations using log annual earnings tell a similar story, with the earnings of the older workers rising relative to those of younger workers, especially among the college educated.

Vie conclude that there was, in fact, a substantial change in the ageearnings profiles for male workers during the period when the number of young workers increased relative to the number of older workers. Are these two changes causally linked? To what extent can the twist in the age-earnings profile against the young be attributed to the sharp increase in the relative number of young workers?

\section{Labor Demand and Age-Earnings Profiles}

In the framework of standard labor demand analysis, the impact of changes in the relative supply of workers by age on wages depends on the substicutability of inputs. When labor of different ages is readily substitutable for other inputs, large changes in supply will cause only modest changes in wages by age. Conversely, when substitutability is limited, sizeable changes in age-earnings profiles are needed for demand to adjust to changes in the age composition of the work force. Since the number of workers of different ages is taken as exogenously determined by demographic changes, the demand for labor schedule becomes a wage determination schedule, linking factor prices to factor quantities. In such a model, Hicks' elasticity of complementarity, which relates factor prices to inputs (see Hicks, Sato and Koizuma) is the appropriate elasticity concept, rather than the standard Allen elasticity of substitution. In this study I will concentrate on the inverse of the Hicks elasticity, defined as: 
(2) $\dot{S}_{i j}=\left(\dot{W}_{i} / \dot{L}_{j}\right) 1 / \alpha_{j}$

where $W_{1}=$ vage of factor $i$

$\mathrm{L}_{\mathrm{i}}=$ amount oi factor $\mathrm{i}$

$\alpha_{j}=$ share of factor $j$ in cost

and where dots above variables represent log changes (i.e. $\dot{H}_{i}=d \ln _{i}$ ) and where the elasticity $s_{i j}$ is taken with other inputs held \pm ixed but with output allowed to vary. ${ }^{10}$ The "own elasticity" of complementarity $S_{i i}$ is implicitly defined by

(3) $\sum_{j} \alpha_{j} s_{i j}=0$ so that $s_{i i}=-\sum_{j \neq i}\left(a_{j} / a_{i}\right) s_{i j}$.

$S_{i i}$ is negative for normal production functions.

When all inputs vary, the factor price determination equation of factor 1 can be written as: 11

(4) $w_{i}=\sum_{j \neq i} \alpha_{j} s_{i j} \dot{L}_{j}+\alpha_{i} s_{i i} \dot{L}_{i}=\sum_{j \neq i} s_{i j}\left(\dot{L}_{j}-\dot{L}_{i}\right)$

Equation (4) shows how changes in the quantities of all inputs or changes in the quantities of inputs relative to the input $i$ alter the wage of input $i$. To see how changes in inputs alter relative wages, let $i$ index one input (say older workers) and $k$ index another input (say, younger workers), then subtract the factor price equation based on (4) for input $k$ from that for input i to obtain:

(5) $\dot{\mathrm{w}}_{i}-\dot{\mathrm{w}}_{k}=\sum_{j \neq i \neq k}\left[\alpha_{i}\left(s_{i j}-s_{k j}\right) \dot{\mathrm{L}}_{j}\right]+\alpha_{i}\left[s_{i i}-s_{k i}\right] \dot{\mathrm{L}}_{i}-\alpha_{k}\left[s_{i k}-s_{k k}\right] \dot{\mathrm{L}}_{k}$.

When factors other than $k$ and $i$ do not affect the ratio of their marginal products, the elasticity of complementarity is equal to one divided by the standard Allen elasticity of substitution (see Hicks, Sato and Koizuma), giving the following relative wage determination equation:

(6) $\dot{\mathrm{W}}_{i}-\dot{\mathrm{W}}_{\mathrm{k}}=\left(1 / \sigma_{1 k}\right)\left(\dot{\mathrm{L}}_{i}-\dot{\mathrm{L}}_{k}\right)$

where $\sigma_{i k}=$ elasticity of substitution between $i$ and $k$. 
Production functions and elasticities

The relevant elasticities of complementarity or substitution for workers in different age groups are estimated in this study assuming one of two functional forms for the production process: the constant elasticity of substitution (CES) form and the translogarithmic (TL) form.

The CES form has both desirable and undesirable features for empirical analysis of the effects of changes in the relative number of workers by age on age-earnings profiles. On the positive side, since the CES has only one elasticity of substitution, the appropriate relative wage equation is of the form of (6), which is reasonably simple to estimate and which provides direct information on the impact of relative quantities on relative earnings. The possibility that changes in relative wages, of the type observed in the 1970s, are due largely to cyclical rather than demographic changes can be readily examined with equation (6) by addition of variables measuring the business cycle. The major disadvantage of the CES is that it cannot be used to test the possibility that in a consistent production function framework changes in other factors, such as capital, may be influencing the relative demand for labor of different ages.

The translogarithmic production function provides an appropriate system for examining the effect of changes in the supply of several inputs on age-earnings profiles. The TL form yields a consistent system of demand equations with potentially different elasticities of complementarity (or substitution) between any pair of inputs. In the translog production system, the production function is:

(7) $\quad \operatorname{lnY}=A+\sum_{i} \alpha_{i} 1 n L_{i}+1 / 2 \sum_{i j} \sum_{i j} 1 n L_{i} 1 n L_{j}$ 
The derived demand equations are:

$$
\text { (8) } \quad \alpha_{i}=a_{i}+\sum_{j} \gamma_{i j} l n L_{j}
$$

subject to cross equation and within equation restrictions on the parameters

$$
\begin{aligned}
& \text { (9) } \sum a_{i}=1 \\
& \text { (10) } \sum_{j}^{\sum \gamma_{i j}}=0=\sum_{i} \gamma_{i j}
\end{aligned}
$$

where $\alpha_{i}=$ share of input $i$ in cost

$$
L_{j}=\text { amount of input } j \text {. }
$$

Equation (8) relates the share of each input in cost to the quantities of inputs; since quantities are given, the equations are in effect relative wage equations, dependent on how the wage components of cost change when quantities change. The Hicks elasticities of complementarity can be readily derived from the translog system by differentiation with respect to the relevant $L_{i}$ and appropriate algebraic manipulation using the fact that $S_{i j}=f f_{i j} / f_{i j} f_{j}$ (See Sato and Koizumi, p. 47). The resultant equations are: ${ }^{12}$

$$
\begin{aligned}
& \text { (11) } s_{i j}=\frac{\gamma_{i j}}{a_{i j} \alpha_{j}}+1 \\
& \text { (12) } s_{i i}=\left(1 / \alpha_{i}\right)^{2}\left[\gamma_{i i}+\alpha_{i}^{2}-\alpha_{i}\right]
\end{aligned}
$$

Equations (11) and (12) relate the elasticities of complementarity to the parameters of the equation and factor shares.

The TL system has one major advantage as a model of demand: it provides estimates of elasticities of complementarity for more than two inputs in a consistent production function framework. It has two disadvantages. First, specification or measurement error in the equation for a factor of only marginal concern, such as for capital in the case at hand, can greatly impact estimates of the demand equations for other factors. Second, the TL model is an equilibrium model that cannot be readily modified to 
allow for the effect of cyclical factors on relative demands.

Since neither the CES nor TL models of production or demand are without problems, the effect of the age composition on relative wages by age will be estimated using both models. By using two functional forms, each of which has weaknesses and strengths, I hope to obtain a better $f$ ix on the key demand relation under study than could otherwise be done.

\section{Determinants of Change in Male Age-Earnings Profiles}

Table 4 presents estimates of the impact of the ratio of the number of younger workers to the number of older workers, the state of the business cycle, and a general trend on the curvature of male age-earnings profiles. The dependent variables in the calculations are the $\log$ of the income of 45-54 year old men relative to the income of $25-34$ year old men ( 1 ines $1-5$ ) and the $\log$ of the income of 45-54 year old men relative to the income of 20-24 year old men ( 1 ines 6-8). Lines $1-2$ and 6-7 refer to the incomes of yearround full-time workers. As noted earlier, these incomes provide a better measure of wages than do the incomes of all workers; unfortunately they are not available until 1955. Lines 3 and 8 treat the ratio of the mean income of all men with non-zero incomes in the relevant age groups over the period 1947-1974. These figures provide additional time series variation in the data at the expense of potential confounding of changes in utilization of labor with changes in wage paid. Lines 4 and 5 consider the age-earnings profiles of college graduates and high school graduates separately for the limited number of years for which such figures are available.

There are three independent variables. The changing age structure 
of the work force is measured by the $10 \mathrm{~g}$ of the ratio of the number of male workers aged 45-54 to the number aged 25-34 (1ines 1-5) or to the number aged 20-24 (lines 6-8). To test the possibility that changes in relative earnings by age are dominated by cyclical rather than demographic factors, the calculations also include a measure of the state of the business cycle, the deviation of the 1 og of real gross national product (GNP) from its trend level: positive deviations reflect a strong economy while negative deviations are indicative of recession conditions. This measure of the cycle is highly correlated with such alternative business cycle indicators as the rate of unemployment or the difference between actual and potential gross national product (see Freeman, 1973). Because of the operation of formal seniority systems and because older workers will have cumulated specific human capital while young workers will not, labor demand is likely to be more cyclical for young than for older workers, suggesting that the deviation of real GNP from trend will be negatively related to the ratio of income of older to younger workers. The third independent variable, a time trend, is introduced to control for any of a variety of factors (greater education of the young, gradual shifts in industrial structure) which might influence the demand for young as opposed to older male workers and thus the relevant income ratios.

The regression results suggest that, with trend and cyclical factors fixed, the relative number of older to younger workers has a significant impact on male age-earnings profiles. In the calculations focusing on the income of 45-54 year olds relative to 25-34 year olds, the measure of relative numbers by age obtains a significant negative coefficient, except among high school graduates (Iine 4). In line 1, which analyzes the incomes 
of year-round and full-time workers with the trend variable omitted, the $\log$ of the ratio of the number of 45-54 year old to the number of 25-34 year old workers obtains a coefficient of -.27 , three times its standard error. Inclusion of the trend in line 2 reduces the coefficient on relative numbers substantively, but still leaves a significant relation between relative numbers by age and relative incomes by age. In line 3 , which treats the Income of all men over the period 1947-1974, the coefficient on the relative number is a highly significant -.20 .

The regressions for the income of year-round full-time workers aged 45-54 relative to the income of year-round ful1-time workers aged 20-24 in lines 6 and 7 also yield sizeable significant coefficients for the relative number of workers by age, though in these cases addition of the time trend raises rather than reduces the estimated coefficients. In line 8 , by contrast, the ratio of the number of 46-54 year old workers to the number of 20-24 year olds has no apparent impact on relative incomes. This is due largely to the trend term, which is highly collinear with the relative numbers variable over the period: with trend deleted, the coefficient on relative numbers in regressions explaining the ratio of the income of 45-54 year olds to the income of $20-24$ year olds is -.31 with a standard error of .09 .

The business cycle indicator, the deviation of real GNP from its trend has little impact on the income ratios of year-round and full-time male workers in lines 1 and 2, suggesting that the wages of 25-34 year old men are no more sensitive to the cycle than those of 45-54 year old men. In the regression for all male workers in line 3 , however, the cyclical variable is accorded a sizeable effect, which presumably reflects the greater cyclical sensitivity of the time worked of the younger men. 
Table 4: Demographic and Trend Determinants of the Mean Income of Older to Younger Male Workers, 1947-1974

ependent Variables (in In units)

ncome of 45-54 year olds relative o the income of $25-34$ year olds

- year-round and full-time workers, 1955-1974

- year-round and ful1-time workers, 1955-1974

- àll workers, 1947-1974

- four-year college graduate workers, 1956-1974b

- high school graduate workers, $1956-1974^{\mathrm{b}}$

ncome of 45-54 year olds relative 0 the income of $20-24$ year olds

- year-round and full-time

workers, 1955-1974

- year-round and ful1-time

income, 1955-1974

- all workers, 1947-1974

Coefficients and Standard Errors

$\mathrm{R}^{2} \quad$ Durbin-

constant CYCLE ${ }^{a}$ Relative Time

Watson

number of

workers

by age

$\begin{array}{llllll}.04 & .08 & -.27 & & .34 & 0.33 \\ .00 & (.26) & (.09) & & & \\ & .01 & -.14 & .005 & .89 & 1.79 \\ .09 & (.11) & (.04) & (.001) & & \\ & -.29 & -.20 & .003 & .54 & 1.70 \\ .09 & (.14) & (.05) & (.001) & & \\ & -.24 & -.51 & .006 & .33 & c \\ .15 & (.64) & (.28) & (.005) & & \\ & -.26 & -.07 & .003 & .48 & c \\ & (.12) & (.11) & (.003) & & \end{array}$

$\begin{array}{llllll}.60 & -.72 & -.32 & & .84 & 1.04 \\ & (.24) & (.04) & & & \\ .69 & -.70 & -.41 & -.003 & .85 & 1.05 \\ & (.25) & (.19) & (.006) & & \\ .59 & -.71 & -.01 & .011 & .86 & 1.92 \\ & (.26) & (.05) & (.001) & & \end{array}$

ource: Income data and numbers from U.S. Bureau of the Census, Current Population Reports, Consumer Incnme Series P-60, various editions. The figureson mean incomes for the period 1947-1960 are from U.S. Bureau of the Census, Trends in Income of Families and Persons in the United States: 1947-1960, technical paper no. 7. Due to the absence of mean figures for the years 1961-1964, mean incomes for those years were obtained by interpolation using least squares regression of the $10 \mathrm{~g}$ of the mean incomes of the $\log$ of median incomes.

College incomes: U.S. Bureau of Census, Current Population Report, Series P-60, no. 92, table A, p. 2 with 1965-1967 ungrouped data spliced for consistency with $1967-72$ grouped data using the 1967 overlap year. The missing year 1965 was obtained by applyin: percentage changes in median incomes from 1964 to 1965 . 1973 and 1974 are taken from series.P-60 no. 97 and no. 101. Because the 1965 income figures were published only for men with 4+ years of college, I estimated the income of 4-year graduates in 1956 by regressing income for 4-year graduates on income for graduates with 4 or more years of college, using all the years after 1956, and extrapolating with the equation

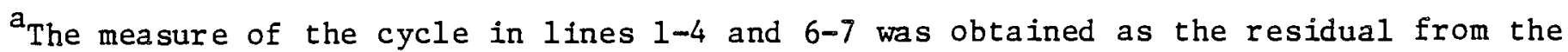
following regression of real GNP on time for the period 1955-1974:

$$
\log \mathrm{GNP}=8.32+. .039 \mathrm{~T} \quad \mathrm{R}^{2}=.983 \text {. }
$$

The measure of the cycle in 1ines 5-8 was obtained as the residual from the following regression of real GNP on time for the period 1947-1974:

$$
\log \mathrm{GNP}=\varepsilon .02+\underset{(.001)}{.037 \mathrm{~T}} \quad \mathrm{R}^{2}=.989 .
$$

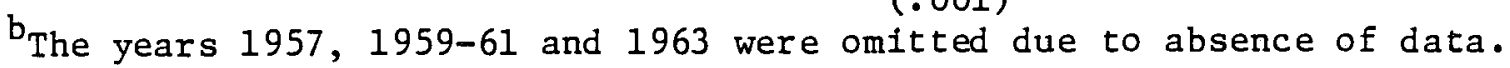

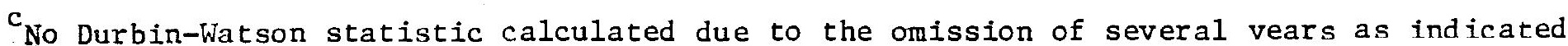


Much stronger cyclical effects are obtained in the calculations for the income of 45-54 year old men relative to the income of 20-24 year olds in lines 6-8, indicating that cyclical ups-and-downs have their greatest impact on the incomes of 20-24 year olds.

The regressions in lines 4 and 5, which focus on the age-earnings profiles of college graduates and high school graduates, respectively, suggest that the increased number of young male workers relative to the number of older male workers had an especially large impact on college graduates profiles compared to only a modest impact on high school graduates profiles. Similar results based on different models and data, have also been obtained by other scholars. Using the Michigan Panel Survey on Income Dynamics, William Johnson found that the relative size of a cohort significantly reduced the impact of the earnings of college graduates but had little effect on the earnings of less educated workers (p. 13). Using the CPS Demographic files, Finis Welch found a significant effect of cohort size on earnings in all school groups, with however much larger elasticities for college graduates. All of these results suggest that younger and older workers are better substitutes in the lower schooling groups than in the college graduate group, and hence that increases in the number of young persons will reduce the earnings of young high school men. This is consistent with the much heralded fall in the rate of return to investment in college education. The regression estimates in Table 4 can be used to gage the impact of the demographic, cyclical; and trend variables on the 1970 s decline in the relative income of young workers by multiplying the coefficients on the explanatory variables by the observed changes in the variables.13 For year-round and full-time workers whose incomes are closest to the wages 
of concern, such an analysis attributes most of the change to demorgaphic factors:

$$
\begin{aligned}
& \text { 45-54 year olds! } \\
& 25-34 \text { year olds }
\end{aligned}
$$

Actual Change in $\log$ income ratios, year-round and full-time workers, 1968-1974

Change predicted by regression model and actual change in independent variables

Due to change in relative number of workers by age

Due to cyclical change

Due to trend
.06

.06
45-54 year olds/ 20-24 year olds

.18

.06

Source: Calculated from regressions 2 and 7 of table 4 and actual changes in explanatory variables

According to these calculations, the regression model explains much of the 1968-1974 increased curvature of cross-sectional age-earnings profiles in terms of the increased number of younger workers relative to the number of older workers. Half of the .06 point increase in the 1 og of the ratio of the income of 45-54 year old to the income of 25-34 year old workers is attributed to the increase in the number of 25-34 year old workers relative to the number of 45-54 year old workers while $60 \%(.11 / .18)$ of the increase in the 1 og of the income of 45-54 year olds relative to the income of 20-24 year olds is explained by the increased number of 20-24 year olds relative to the number of 45-54 year old workers. The trend variable accounts for the remainder of the change in the income ratio of 45-54 to 25-34 year olds while the cyclical variable explains most of the remaining change in the 45-54 to 20-24 year olds income ratio.

In sum, the estinated effects of demographic, cyclical, and trend factors using relative income equations based on CES-type functional forms suggest that the observed twist in the age-earnings profile 
against young men can be attributed in large part to the changed age structure of the work force, 14

\section{Translog System Estimates}

The effect of changes in the ratio of the number of younger to the number of older male workers and of changes in the amount of other inputs on male age-earnings profiles can be analyzed with the translog system of demand derived equations (9)-(11). Such an analysis enables us to check on the robustness of the results of table 4 under a different functional specification and to test two competing hypotheses about the causes of the observed twist in male age-earnings profiles: 1) That the twist results from increases in the amount of capital, which shifts demand for labor toward older as opposed to younger workers. Increases in capital would have such an effect on demand if, as seems reasonable, capital is relatively more complementary (less substitutable) with older than with younger workers. One reason for expecting relatively greater complementarity is that skilled labor has been found to be relatively more complementary with capital than unskilled labor (Griliches). Since older workers tend to be more skilled than younger workers, demand for the former could be expected to be relatively more complementary with capital. Another is that older workers presumably have also accumulated greater specific human capital, linked to physical capital. 2) That the twist in the male age-earnings profiles is due to the influx of female workers, who are better substitutes for young male workers than for older male workers. The reason for expecting greater substitutability between women and younger men than between women and older men is that women are more likely to be competing for entry level or early career jobs than for more senior positions in firms. If women are better substitutes for the young, then increased numbers of women workers would raise the earnings of older men relative to younger 
men.

A translog derived demand system was estimated with the number of ful1time equivalent female workers aged 20-34, the quantity of capital, and number of full-time male equivalent workers aged 20-34, and the number of full-time and equivalent male workers aged $35-64$ as inputs. Workers below the age of 20 were eliminated due to serfous problems in estimating their earnings. Male workers were divided into two groups due to the problems of estimating translog systems with more than four inputs using a limited number of observations. The younger of the two groups, 20-34 year olds, covers the 20-24 and 25-34 year olds treated in earlier tables.

The inclusion of women and capital in the analysis creates considerable data problems due to inadequate information on the amount and rewards of these inputs. The problem for women is that published CPS figures have historically reported incomes and the number of persons with income rather than labor market earnings, and workers with earnings. Since many women have income but do not work in the labor market, it is imperative to adjust the data to take account of this difference. Comparison of the mean earnings of women to the mean income of women in recent years when both figures were published in the Current Population Reports show little differences (less than $1 \%$ in 1974 , for example), ${ }^{15}$ suggesting that the mean incomes provide reasonable estimates of mean earnings. Comparisons of the number of persons with income and with earnings, however, reveal a sizeable differential. In 1974, for example, $38 \%$ more women were reported as having income than were reported as having earnings. ${ }^{16}$ To take account of this problem and of the part-time work done by many women employees, the number of full-time equivalent women working in the U.S. was estimated by adjusting data from the Employment and Training Report of the President 1977, by estimates of weeks worked from the Work Experience of the Population reports of the B.L.S. 
as described in the table note. These figures were multiplied by the mean incomes given in Trends in Income of Families and Persons in the United

States and by mean incomes in the Consumer Income Series P-60, to obtain factor payments to women. Comparable estimates of employment of men aged 20-34 and 35-64 were made from the same source and multiplied by the mean incomes for those age groups to obtain the factor payments going to younger and older men.

The problem with data on capital is that we lack good information on both the capital stock and user cost. An estimate of private capital was made from data on corporate and noncorporate investment in nonresidential business capital, provided by the U.S. Department of Commerce (Musgrave 1976) and unpublished data on goverment capital stock from the same source. The user cost of capital is based on methodology developed by Jorgenson and associates. The particular measure used takes into account the differential tax treatment of equipment and structures and the presence of both equity and debt finance, and adjusts the cost of capital for depreciation and expected capital gains. It is based on a weighted average of the user cost of equipment and the user cost of structures, with weights taken as the share of each in total investment from the National Income and Product Accounts. The precise estimating procedure is described in detail in Clark and Freeman.

The shares of each of the inputs in cost was estimated by dividing the total factor payments to each by the sum of factor payments. In the sample the mean share of national income going to men aged $35-64$ was .39; the share going to men aged 20-34 was .18; the share going to women aged 20-64 was .12; while the share going to capital was .31. Though the data leave much to be desired, they provide at least a crude means of examining in the context of the translog specification the effect of the increased supply of women and capital on the age-earnings profiles of men. 
Estimates of the constrained translog system were made with an interative version of Zellner's minimum distance estimator. Given the constraints, one of the factor share equations is redundant and can be dropped without affecting results: the capital share equation was deleted.

Table 5 records the estimated parameters of the system. Table 6 presents the elasticities of complementarity and of factor prices with respect to changes in quantities derived from the parameters at the mean value of the shares. In all cases the elasticities of input prices with respect to the quantity of the same input are negative, as required by the model. All of the labor inputs are complementary with capital (i.e., have positive elasticities of complementarity). As hypothesized, however, older men are relatively more complementary with capital and have a larger elasticity of factor price with respect to capital than do younger men (the relevant $S_{i j}$ 's are 1.76 for men aged 35-64 and 1.47 for men aged 20-34; the relevant factor price elasticities are .55 for men aged 35-64 and .46 for men aged 20 to 34 ). Contrary to expectation, the number of women is estimated to have a slight positive effect on the earnings of young men compared to a slight negative effect on the earnings of older men. The magnitudes of those elasticities of complementarity and of the elasticities of factor prices between the female work force and the two age groups of men are, however, sufficiently slight as to suggest that male and female workers operate in essentially separate production processes. Given the problems noted above in estimating the input of female labor, however, little weight ought to be given to the link between the female work force and demand for other factors.

The most important finding from the TL system regressions is that, consistent with our previous results, the earnings of men aged 20-34 depend critically on the number of young male workers. The own elasticity of complementarity for the number of young men is sizeable negative and far in excess of the cross-elasticity between young and older men, implying that an Increase in the number of young men would reduct their wage relative to the 
wage of older men. Most importantly, the estimated factor price elasticities indicate that changes in the numbers of male workers of different ages will substantively influence the earnings of younger and older men and thus are likely to alter male age-earnings profiles.

The quantitative contribution of changes in the various inputs on male age-earnings profiles in the period when the profiles changed sharply can be evaluated by substituting the estimated elasticities of factor prices with respect to quantities from table 6 into the relative wage determination equation (5) derived in section III and multiplying the resultant coefficients by the actual changes in the inputs. Let $\dot{\mathrm{L}}_{\mathrm{w}}=$ the $\log$ change in the input of female labor, aged 20-64 and $\dot{K}=$ the Iog change in the capital input. Then plugging the factor price elasticities from the table into equation (5), rields:

(14) $\dot{\mathrm{W}}_{35-64}-\dot{\mathrm{W}}_{25-34}=.33 \dot{\mathrm{L}}_{25-34}-.39 \dot{\mathrm{L}}_{35-64}-.04 \dot{\mathrm{L}}_{\mathrm{w}}+.09 \dot{\mathrm{K}}$

as the appropriate equation determining the earnings of older men relative to younger men. From 1968 to 1974 the four inputs changed as follows: $\dot{\mathrm{L}}_{25-34}=.24 ; \dot{\mathrm{L}}_{35-64}=-.02 ; \dot{\mathrm{L}}_{\mathrm{w}}=.17 ; \dot{\mathrm{K}}=.11$ while $\dot{\mathrm{W}}_{35-54}-\dot{\mathrm{W}}_{25-34}=.07$.

This yields the following decomposition of the change in relative incomes:

Actual change $\left(\dot{\mathrm{W}}_{35-64}-\dot{\mathrm{W}}_{25-34}\right), 1968-1978 \quad .07$

Change predicted by translog model and actual change .07 in independent variables

Due to changed number of young men $\left(\dot{L}_{y}\right) \quad .08$

Due to changed number of older men $\left(\dot{\mathrm{L}}_{0}\right) \quad-.01$

Due to changed number of females $\left(\dot{\mathrm{L}}_{\mathrm{w}}\right) \quad-.01$

Due to changed stock of capital $\left(\dot{\mathrm{L}}_{k}\right) \quad-.01$

Source: Calculated using (14) and actual changes in explanatory variables. 
Table 5 Estimates of Derived Demand

Equations of the Translog Cost System, 1950-157! a

1. constant

2. In male workers 20-34

3. In male workers $35+$

4. In female workers $20+$

5. In capital

6. $\mathrm{R}^{2}$

7. SEE

8. D.W.

male workers
20-34

share of inputs male workers $35+$

$.1 .73(.001)$ $.404(.003)$ $.080(.006)$

$-.088(.006)$

$-.018(.006)$

$.026(.009)$

.767

.0035

1.52
$-.088(.006)$

$.051(.011)$

$-.054(.007)$

$.092(.011)$

.674

.0110

0.49

female workers
$20+$

$.112(.002)$

$-.018(.006)$

$-.054(.007)$

$.021(.008)$

$.052(.012)$

.861

.0008

0.69 [capita1]

.301

$.026(.009)$

$.092 .(.011)$

$.052(.012)$

$-.170(.020)$

$-$

${ }^{a}$ Numbers in parentheses are standard errors. Dependent variables are shares of inputs.

Capital equation omitted; estimated obtained from constraints

Source: Income share calculated using incomes of workers from Current Population Survey, Consumer Income Reports, various editions and numbers of workers employed from U.S. Department of Labor, Employment and Training Report of the President 1976, table A-14, p. 232. Because men and women workers are employed different numbers of hours over the year, the numbers uscd as explanatory variables were adjusted to reflect approximate hours worked. Data on weeks work $\epsilon$ by part-time and full-time employees by sex and age were obtained from U.S. Department of Labor, Work Experience of the Population, 1969, table A-1a, p. A-9, full-time equivalents were calculated by estimating the mean weeks worked by full-time workers and part-time workers, with the former assumed to work 40 hours per week and the latter 20 hours per week. Estimates were made for a single year 1969 for men aged 20-34 and 25-34, men aged 35-64 and women aged 20-64. The mean weeks for the groups were: males 20-24, 35; men 25-34 and 35-64, 48; women 20-64, 37. Accordingly the number of female employees was adjusted downward by $37 / 48$ and the number of men $20-24$ by $35 / 48$. The figures were obtained from U.S. Bureau of Labor Statistics, Capital obtained from Musgrave (1976) and unpublished U.S. Department of Commerce data. The price of capital was obtained from Clark and Freeman, as described in the text. Estimates were made by LSQ part of Time Series Processor program. 
Estimates of Elasticities of Complementarity and of the Elasticity of Factor Trices to Changes in the Quantity of Inputs, Evaluated at the Mean Shares of Factors in Cost

The Elasticity of Complementarity $s_{i j}$, by Group

Men 20-34 Men 35-64 Women 20-64 Capital

$-2.09$

$-.25 \quad-1.25$

.17

1.47

$$
-.15
$$$$
-5.88
$$

1.76
Elasticities of Factor Prices With Respect to \begin{tabular}{llll}
\multicolumn{2}{c}{ Changes in Quantities, by Group } & \\
Men 20-34 Men 35-64 Women 20-64 Capital
\end{tabular}
$-.38$

$-.10$

.02

.46
$-.05$

$-.49$

$-.02$

$-3.95$

.55
.03

$-.06$

$-.71$

.73
.26

.69

$-.29$

$-1.23$
4, Capital

Source: Elasticity of complementarities calculated from the estimates of $\gamma_{i j}$ and $\gamma_{i i}$ in table 6 using the formula

$$
\begin{aligned}
& s_{i j}=\left(1 / \alpha_{i} \alpha_{j}\right) \gamma_{i j}+1 \\
& s_{i i}=1 / \alpha_{i}^{2}\left(\gamma_{i j}+\alpha_{i}^{2}-\alpha_{i}\right)
\end{aligned}
$$

Elasticities of factor prices computed as $\alpha_{j} S_{i j}$ and $\alpha_{i} s_{i i}$. 
According to these calculations the increased supply of young men was the principal factor depressing their earnings relative to the earnings of older men from the late 1960s to the mid 1970s. ${ }^{17}$

\section{Conclusion}

The analysis in this paper has shown that from the late 1960s through the mid 1970s when the number of young workers increased rapidly, the earnings of young male workers fell relative to the earnings of older male workers, altering male age-earnings profiles, particularly for college graduates. Demand for labor equations based on the constant elasticity of substitution production function and on the translogarithmic production function suggest that the increased number of young male workers was the major causal force underlying the increased earnings of older men relative to the earnings of younger men. Alternative factors that might explain the observed twist in male age-earnings profiles-the business cycle, general trends, the increased supply of women, and growth of capital--were found to have much smaller effects on age-earnings profiles.

The late 1960 s to mid 1970s twist in male age-earnings profiles raises important questions about the effect of the size of a cohort on the earnings of the cohort and about the economic determinants of crosssectional differences in earnings by age. Will the relatively low earnings of the lage young cohorts of the 1970 s be maintained in the future? Will age-earnings profiles change in favor of the prospective small youth cohorts of the 1980s? Do demographic swings produce significant intergenerational income inequality? How important are differences in the relative size of cohorts in determining the shape of cross-sectional age-earnings profiles? 
Arguments can be advanced for and against the likely permanance of a "cohort effect" on the earnings of the young (20-34 year old) male workers of the 1970 s.

Three basic forces would appear to operate to create permanent cohort effects. First is the tendency of many firms to promote individuals by seniority along well-defined job ladders and to raise pay through 'standard' increases over starting rates. With this type of pay policy a group that enters the market with low earnings compared to others will never catch up to the position it would have had had it entered with higher initial earnings. Second is the possibility that the large young worker cohort of the 1970 s has been "pushed" into jobs with flatter longitudinal age-earnings profiles than are normally chosen by young workers (as may be occurred among college graduates, some of whom have been unable to obtain "college type" jobs). While some of the young may be able to switch to jobs with steeper earnings trajectories in the future, the overall rate of increase in pay may still fall short of what would have occurred for a smaller cohort that obtained more desirable jobs at the outset. Third, to the extent that future promotions and raises will be depressed by competition from a large pool of persons in the same age groups, the large youth cohorts of the 1970s may actually lose ground in the job market relative to other cohorts in the future.

On the other side of the spectrum, if the low initial earnings of persons in the 1970 s are given a strict investment interpretation, they suggest that young workers are making greater investments in on-the-job training than in the past, presumably through selection of "learning jobs." This will show up in especially steep longitudinal profiles for this cohort in the future and thus in significant catching up. Perhaps more realistically, the likelihood that substitution among workers of different ages increases with age suggests at least some diminution in 
the effect of cohort size over time (Welch).

Limited evidence on cohort earnings profiles in the past and on the jobs held by the new entrants of the 1970 s suggests that some permanent effect of cohort size on earnings is likely. Ruggles and Ruggles' analyses of the social security (LEED) data file reveal a noticeable drop in the longitudinal profile for the cohort which entered the labor force in about 1930, apparently because 'the labor market conditions at the time of their entry had a significant depressing effect on their earnings, relative to those who preceded them and were already established in the labor market,' whereas the earnings of the cohort born a decade later were 'high relative to the cohorts surrounding them and seem to have enjoyed this advantage continuously' (p. 124). Chamberlain's evidence on the return to schooling addresses directly the possibility that the relatively depressed position of young college graduates compared to high school graduates is a temporary phenomenon due to greater investments in on-the-job training. His estimates of the return to schooling at the "overtaking point," (when earnings are no longer depressed by investments) suggest a drop from $12 \%$ in 1969 to $7 \%$ in 1973. Finally, the marked decrease in the proportion of new college graduates (see Freeman, 1976, 1977), in professional and managerial jobs, where the profiles are traditionally the steepest, suggest that it will be difficult for young college workers to 'catch up' significantly in the future. Overall, while some catch up is likely, it appears more likely on the basis of current information that the large youth cohorts of the 1970 s will suffer some loss in earnings compared to the smaller cohorts that preceeded them and to the smaller cohorts that will enter the job market in the 1980 s.

Developments in the 1980 s should provide, at the least, an interesting 'test' of alternative interpretations of the determinants of changes in 
male age--earnings profiles. If relative wages by age shift in favor of young workers when the number of young workers declines in the mid to late $1980 \mathrm{~s}$, the imoortance of demographic factors as determinants of male age-earnings profiles will be given further support. If the large youth cohorts of the 1970 s do not experience especially rapid longitudinal gains in earnings in the eighties, the incompleteness of the standard interpretation of cross-section profiles in terms of investments in training will be further demonstrated. Opposite patterns will, of course, have contrary implications. Finally, while the importance of demographic and demand factors relative to investments in human capital as determinants of age-earnings profiles remains to be seen, the experience of the 1970s and earlier analyzed in this study does suggest that greater consideration be given to demand for labor by age in analyzing male age-earnings profiles. 
Footnotes

${ }^{1}$ For models of the link between birth rates and the age distribution of workers see Keyfitz.

${ }^{2}$ All of the data in this paragraph are from U.S. Department of Labor, Employment and Training Report of the President 1977, table A-2, p. 137 and from U.S. Department of Labor, Bureau of Labor Statistics, "Educational Attainment of Workers," Special Labor Force Reports, various editions.

${ }^{3}$ Figures on high school graduates are from U.S. Bureau of the Census, Statistical Abstract of the U.S. 1977, P. 153. Figures on civilian labor force from U.S. Department of Labor, op. cit., table A-3, p. 139.

${ }^{4}$ Figures on high school graduates and dropouts in the labor force from U.S. Department of Labor, Bureau of Labor Statistics, "Employment of June 1970 High School Graduates" Special Labor Force Reports No. 15. table 2 and from Handbook of Labor Statistics 1977, table 31, p. 77. Data on civilian labor force from Employment and Training Report of the President 1977, table A-3.

${ }^{5}$ See the estimates given in R. Freeman, The Overeducated American (Academic Press, 1976, pp. 67-68).

${ }^{6}{ }_{\text {Let }} W_{1974}^{\prime}=$ income in 1974 calculated by old inputation procedure $\mathrm{W}_{1974}=$ income in 1974 calculated by new inputation procedure $\mathrm{W}_{1975}=$ income in 1975 calculated by new inputation procedure. Then the adjustment is $\left(W_{1974}^{\prime} / W_{1974}\right)\left(W_{1975}\right)$.

${ }^{7}$ This statement is simply a speculative hypothesis. Groups of workers could have similar earnings for any number of reasons unrelated to elasticities of substitution. Moreover, a high elasticity of substitution need not produce similar wages for groups of workers. 
${ }^{8}$ The sampling errors reported in the U.S. Bureau of the Census, Current Population Reports, Series P-60 can be used to make statistical tests of changes in incomes but are not well suited to test changes in ratios of incomes.

${ }^{9}$ Unfortunately, there is no way to deal directly with the problem of changes in imputation procedures between the 1969 and 1978 March CPS tapes. Prior to 1976 the public use tapes do not contain "flags" for impated earnings, making comparable regressions impossible. As the new imputation procedure appears to have greatly affected the earnings of workers by education but not by age, however, the results are unlikely to be seriously marred by this problem. Regressions with the March 1975 tape (which used the old imputation procedure) give, in any case, results much like those found with the March 1978 tape. For a detailed discussion of the imputation problem, see U.S. Bureau of the Census, Current Population Reports, Consumer Income Series $\mathrm{P}-60$, No. 105. That report shows that age comparisons are on $1 \mathrm{y}$ modestly biased by the change in imputation procedure, but that education comparisons are seriously biased. There is a marked jump in the relative earnings of college graduates in the March 1976 tapes due to the new imputation procedure.

10 Output must be allowed to vary in this experiment because the quantity of inputs is changing, which will change output.

${ }^{11}$ To derive (4) rewrite (2) as $\dot{W}_{i}=a_{j} S_{i j} \dot{L}_{j}$. This gives the change in $\dot{H}_{i}$ due to changes in $\dot{L}_{j}$, all else the same. To get the change in $\dot{W}_{i}$ due to changes in all factors, we sum $\dot{W}_{i}=a_{j} s_{i j} \dot{L}_{j}$ across $j$, which yields the expression (4) in the text.

12 Since $\alpha_{i}=x_{i} f / f$ we rewrite (8) as $f_{i}=f\left(a_{i}+\sum \gamma_{i j} \ln x_{j}\right) / x_{i}$. Then $f_{i j}=$ $\left(f \gamma_{i j} / x_{i} x_{j}\right)+f a_{j}\left(a_{i}+\sum \gamma_{i j} 1 \Omega x_{j}\right) / x_{i}$. Since $f_{i} / f=\left(a_{i}+\sum \gamma_{i j} 1 n x_{j}\right) / x_{i}$ the right hand side of the expression can be 
further simplified to $\left(f \gamma_{i j} / X_{i} X_{j}\right)+f_{j} f_{i} / f$. Dividing both sides by $f / f_{i} f_{j}$ yields the expression in the text for $S_{i j}$. Derivation of $S_{i i}$ is similar. ${ }^{13}$ Let $\hat{a}_{i}$ be the estimated effect of variable $x_{i}$ on relative earnings and let $\Delta \mathrm{x}_{i}$ be the change in $\mathrm{x}_{i}$ in the period. Then the contribution of the change in $x_{i}$ to the change in relative earnings is $\hat{a}_{i} \Delta x_{i}$.

14 While the regression calculations "explain" the bulk of the variation in the income of older men relative to the income of younger men, it is important to recognize that some observations do not appear to fit the model. In particular, despite a relatively large number of younger workers in the late 1940s/early 1950s, the age-income profile was not as steeply sloped as the analysis would lead one to expect. This may be the result of the effect of the Great Depression and World War II on the employment experiences of workers or the result of the reduction in female participation at the end of the war. What is needed is a detailed study of the labor market for younger and older workers in that period to determine why relatively large numbers of young workers were 'absorbed' into the work force with little reduction in the earnings of young workers relative to older workers.

${ }^{15}$ In 1974 the mean income of all women was $\$ 4142$. The mean earnings of women with no other income was $\$ 4101$. See U.S. Bureau of the Census, Current Population Reports, Consumer Income Series P-60, No. 101, table 71, p. 145.

${ }^{16}$ In 1974 there were 59.2 million women reporting income and 42.9 million reporting labor market earnings in the U.S. Bureau of the Census, Current Population Reports, Consumer Income Series P-60, No. 101 (table 71, p. 145). These figures are similar to those in other years. 
${ }^{17}$ Using a different data set, with different definitions of age groups and a different time period, Joseph Anderson also has found that a large fraction of the change in the relative wages of the young is due to their increased numbers. However, he also attributes a large portion of the change to greater complementarity between capital and middle aged (25-54 year old) workers than between capital and younger workers, those aged 14-24. While both Anderson's results and those in this study show a depressant effect of the increased relative humber on the wages of workers, they differ in the estimated effect of capital, which may highlight the problems of measuring that variable. Differences in the age groups covered may also explain the moderately different results obtained between Anderson's data set and the one used here. 
Ref erences

Anderson, J "Substitution Among Age Groups in the United States Labor Force," Williams College, December 1978.

Berndt, E., and L. Christensen. "The Translog Function and the Substitution of Equipment, Structures and Labor in U.S. Manufacturing, 1929-1968." Journal of Econometrics (1973), pp. 81-114.

Binswanger, H. "A Cost Function Approach to the Measurement of Elasticities of Factor Demand and Elasticities of Substitution," American Journa1 of Agricultural Economics (May, 1974), pp. 377-386.

Cartter, A. Ph.D.'s and the Academic Labor Market (Carnegie Commission, McGraw-Hill, 1976.

Chamberlain, G. "Omitted Variable Bias in Panel Data: Estimating the Returns to Schooling," Harvard Institute of Economic Research Discussion Paper 618 (May 1978).

Clark, K. and Freeman, R. "ITow Elastic is the Demand for.

Labor?" (NBER Working Paper, 1979).

Freeman, R. "Changes in the Labor Market for Black Labor" Brookings Papers, Summer, 1973, reprinted in A. Smith, Cases and Materials on Employment Discrimination Law, Bobbs-Merill, 1977.

Griliches, 2. "Capital-Skill Complementarity" Review of Economics and Statistics (Nov., 1969), pp. 465-468.

Hicks, J. "Elasticity of Substitution Once Again: Substitutes and Complements," Oxford Economics Papers, Vol. 22, No. 3, Nov. 1970, pp. 289-296.

Johnson, W. R. "Vintage Effects in the Earnings of White American Men," (University of Virginia, October, 1978).

Jorgenson, D. "Capital Theory and Investment Behavior," American Economic Review (May, 1963), pp. 247-259.

Keyfitz, N. Applied Mathematical Demography (New York: John Wiley \& Sons, : $: 7$ ), 
Musgrave, John (1976). "Fi $i_{i:}$ ed Nonresidential Business and Residential Capital in the United States, 1925-1975," Survey of Current Business, Vo1. 56, June. 197 Ruggles, N.D. and Ruggles, R. "The Anatomy of Earnings Behavior" in The Distribution of Economic Well-Being (ed. F. T. Juster), NBER, 1977.

Sato, R. and Koizumi, A. "On the Elasticities of Substitution and Complementarity" Oxford Economic Papers 22, Nov. 1970, 289-96.

U.S. Buiteau of the Census, Current Population Reports nnsumer Income Series P-60, various editions.

U.S. Bureau of the Census, Statistical Abstract 1977 (USCPO), Trends in Income of Families and Persons in the U.S. 19:7-i960.

U.S. Department of Health, Fducation and Felfare, The Condition of Education, 1977 edition, (U.S.G.P.0.), vol. 3, part 1.

U.S. Department of Labor, Employment and Training Report of the President 1975, U.S. Department of Labor, Bureau of Labor Statistics, "Educational Attainment of Workers," Special Labor Force Reports, various editions.

U.S. Department of Labor, Bureau of Labor Statistics, "Employment of High School Graduates and Dropouts," Special Labor Force Report, various editior U.S. Department of Labor, Bureau of Labor Statistics, Work Experience of the Population, 1969.

Welch, F. "Effects of Cohort Size on Farnings: The Baby Boom Babies' Financial Bust," Cambridge University Conference on Income Distribution, 1978. 